Analytical Methods

\title{
Biophysical evaluation of physiological effects of gilthead sea bream (Sparus aurata) farming using FTIR spectroscopy
}

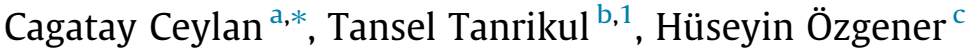 \\ a Izmir Institute of Technology, Department of Food Engineering, Urla, Izmir, Turkey \\ ${ }^{\mathrm{b}}$ Department of Fish Diseases, Faculty of Fisheries, Ege University, İmir, Turkey \\ ' İzmir Institute of Technology, Department of Chemistry, Urla, İzmir, Turkey
}

\section{A R T I C L E I N F O}

\section{Article history:}

Received 27 September 2012

Received in revised form 8 April 2013

Accepted 28 August 2013

Available online 12 September 2013

\section{Keywords:}

Gilthead sea bream

FTIR

Liver tissue

\begin{abstract}
A B S T R A C T
Sparus aurata is one of the two most important cultured fish species in the Mediterranean region. The present work investigates the effects of culturing in $S$. aurata liver tissue at the molecular level using Fourier Transform Infrared (FTIR) spectroscopy. FTIR spectroscopy revealed dramatic differences between the wild and aquacultured fish liver cells, which mainly indicated that the level of glycogen increased in the aquacultured samples and the protein/lipid ratio decreased by $42.29 \%$ indicating that triglycerides and cholesterol esters increased and the protein content decreased in the aquacultured samples. The $15.99 \%$ increase in the level of unsaturation indicated elevated lipid peroxidation. Structural/organisational changes in the nucleic acids along with increased transcriptional status of the liver tissue cells were observed in the cultured fish tissue. All these results indicated that culturing induces significant changes in fish physiology. In addition FTIR spectroscopy is a promising method to monitor the physiological changes in fish physiology.
\end{abstract}

(c) 2013 Elsevier Ltd. All rights reserved.

\section{Introduction}

One of the most important species in fish farming in the Mediterranean region is the carnivorous species gilthead sea bream (Sparus aurata). Therefore aquaculture production of gilthead sea bream has largely increased over the past decade, and this rapid expansion has led to a decrease in the market price of this valuable fish species. Although fish rearing brings economical advantages to economy it imposes significant consequences to fish physiology.

In its niche the wild gilthead sea bream feeds on crustaceae and mollusca. Due to wide variety of nutrition sources and availability of physical activity in their niche the wild gilthead sea bream experiences metabolic disorders at a much lower level when compared to their aquacultured counterparts. Aquaculturing of fish rearing involves use of artificial feeds that differ from the natural prey of carnivorous fish in composition and texture (Hardy, 1989). Such artificial feeds may cause nutritional imbalance and pathological changes in various organs, particularly the liver (Roberts \& Bullock, 1989). Lipoid liver disease, a significant problem in fish feeds, is usually linked to rancidity of fats in fish feeds.

\footnotetext{
* Corresponding author. Address: İzmir Institute of Technology, Department of Food Engineering, Urla, 35430 İzmir, Turkey. Tel.: +90 232750 6328; fax: +90 232 7506196.

E-mail address: cagatayceylan@iyte.edu.tr (C. Ceylan).

1 Current address: İzmir Katip Celebi University, Fisheries Faculty, Aquaculture Department, Çiğli-İzmir, Turkey.
}

The use of the liver as an indicator organ of the nutritional and physiological status in fish is well-known (Segner \& Juario, 1986). Several environmental factors such as temperature, nutritional status and physical activity habits are known to affect the liver composition. One of the common observations on the liver is lipid deposition also known as steatosis commonly recognised as a pathological condition especially in case of dietary disturbances. Metabolic deregulation in the liver cells due to nutritional changes is known to cause structural alterations in the liver cells.

Fourier transform infrared (FTIR) spectroscopy is a rapid, sensitive and nondestructive method which is widely used in the analysis of biological systems in any physical state, and can be used to monitor molecular changes for simultaneous detection of changes in cellular components such as lipids, proteins, carbohydrates and nucleic acids at the level of functional groups. The metabolic changes that result in alterations in carbohydrate, lipid and protein profiles, hence changes in the macromolecular composition of the cells of interest can be analysed using minute amounts of sample and allows analysis of the data with many different digital manipulations. The technique qualitatively and quantitatively evaluates shifts in peak positions, changes in bandwidths and band intensities to obtain structural and functional information about the systems analysed. In addition, FTIR spectroscopy provides information about the amount and chemical and physical nature of the groups in close vicinity (Cakmak, Togan, \& Severcan, 2006; Ceylan et al., 2012).

In this study, we examined the structural and metabolic changes in the liver samples of wild and aquacultured gilthead 
sea bream (S. aurata) by FTIR spectroscopy. For this purpose, the wild and cultured fishes were obtained from commercial resources. Although culturing-dependent macromolecular changes in fish tissues have been investigated using various techniques (Cakmak et al., 2006; Çakmak, Togan, Uğuz, \& Severcan, 2003), this is the first study investigating biochemical variations between wild and cultured gilthead sea bream tissues using FTIR spectroscopy.

\section{Materials and methods}

\subsection{Reagents}

IR-grade Potassium bromide ( $\mathrm{KBr}$ ) was purchased from SigmaAldrich Company (USA)

\subsection{Fish Model}

The aquacultured fishes were obtained from a fish farm. The livers of the wild and cultured fish were removed and stored at $-20^{\circ} \mathrm{C}$ for the FTIR study. The FTIR studies were performed within 2 weeks after the removal of the liver.

\subsection{Sample preparation for FT-IR spectroscopy}

The liver samples were lyophilised in a freeze drier (Labconco, FreeZone 181 freeze dry system) overnight to remove water. The liver powder was mixed with dried potassium bromide ( $\mathrm{KBr}$ ) (Sigma-Aldrich, USA) in a mortar (at a ratio of $1: 100$ ). The mixture was then pressurised to $5000 \mathrm{~kg} / 12 \mathrm{~mm}$ diameter of $\mathrm{KBr}$ pellet (629 psi) for $5 \mathrm{~min}$.

\subsection{FTIR spectrum accumulation and data processing}

The spectral analysis was carried out using a Perkin-Elmer spectrometer equipped with MIR TGS detector (Spectrum 100 Instrument, Perkin Elmer Inc., Norwalk, CT, USA). FTIR spectra of the samples were recorded between 4000 and $450 \mathrm{~cm}^{-1}$. Interferograms were averaged for 20 scans at $4 \mathrm{~cm}^{-1}$ resolution. The background spectrum was automatically subtracted from the spectra of the samples. Spectrum 100 software (Perkin Elmer) was used for all data manipulations.

From each sample, at least three different scans, which gave identical spectra, were performed. These replicates were averaged and the averaged spectra for each sample were then used for further data manipulation and statistical analysis. The spectra were smoothed over 19 points using the Savitzky-Golay algorithm. Then, the spectra were interactively baselined from two arbitrarily selected points. Finally, the spectra were normalised in specific regions for visual comparison of the wild and aquacultured fish liver samples.

\subsection{Statistical analysis}

The differences between the wild and cultured groups were compared using the Mann-Whitney $U$ Test with the Matlab $\mathrm{R} 2010 \mathrm{~b}$ program. The statistical results are expressed as means \pm standard deviation. A $p$ value of less than 0.05 was considered statistically significant.

\section{Results and discussion}

In this study, the physiological differences between wild and cultured S. aurata liver cells were studied at molecular level using the FTIR method.
Fig. 1 shows the average FTIR spectra of wild $S$. aurata liver cells in the $3700-940 \mathrm{~cm}^{-1}$ spectral region. The assignments of the major bands in Fig. 1 are presented in Table 1. All the spectra presented in the figures were normalised with respect to specific selected bands and used only for illustrative purposes. However, in the measurement of the spectral parameters, each original baseline-corrected spectrum belonging to the corresponding control and treated groups was considered separately. In addition, water was removed from the samples in the sample preparation steps using lyophilisation procedures. Although it was reported that dehydration can change the absorption characteristics of cells significantly, the studies were acceptable as long as the cells were always dried (Mourant et al., 2003a). When the comparison of physiological states is investigated dried systems can provide comparative spectral data especially when the hydration levels of the both states are the same. In this study since water was essentially removed from the samples, water's contribution to Amid A, Amid B, Amid I and Amid II bands was negligible.

Fig. 2a and b show the average FTIR spectra of the wild and cultured $S$. aurata liver cells in the $2840-3660 \mathrm{~cm}^{-1}$ spectral region.

Culturing induced remarkable changes in the bandwidth, intensity and frequency value changes of the FT-IR band in this region as can be seen from Fig. $2 \mathrm{a}$ and there is a significant reduction in the intensity of amid $A$ and amid $B$ bands, which are located at $3300 \mathrm{~cm}^{-1}$ and $3064 \mathrm{~cm}^{-1}$, respectively (Cakmak, Zorlu, Severcan, \& Severcan, 2011; Chan, Bocian, \& Petersen, 1981; Elibol-Can et al., 2011). In addition the intensity of the band at $3422 \mathrm{~cm}^{-1}$ decreased with respect to the band at $3300 \mathrm{~cm}^{-1}$ in the cultured fish liver cells considerably.

In the present study, the $3299 \mathrm{~cm}^{-1}$ band can be considered to be due to only proteins and polysaccharides since water was largely removed from the samples. The dramatic reduction observed in the intensity of the band between 3650 and $3100 \mathrm{~cm}^{-1}$ could have resulted from the reduced contribution of proteins. Since the band around $1152 \mathrm{~cm}^{-1}$ increased in the cultured fish liver spectrum the results revealed that glycogen levels increased in the cultured fish liver tissue.

The region between $3020 \mathrm{~cm}^{-1}$ and $2833 \mathrm{~cm}^{-1}$ is populated by absorptions arising from $\mathrm{C}-\mathrm{H}$ stretching vibrations of aliphatic compounds. When normalised to the band at $2925 \mathrm{~cm}^{-1}$, the intensity of the $\mathrm{CH}_{3}$ asymmetric stretch band at $2959 \mathrm{~cm}^{-1}$ and $\mathrm{CH}_{3}$ symmetric stretch band at $2872 \mathrm{~cm}^{-1}$ decreases for cultured fish liver cells, whereas the intensity of $\mathrm{CH}_{2}$ symmetric stretch at $2854 \mathrm{~cm}^{-1}$ increases for cultured fish liver cells. In Fig. 3 the intensity ratio of $2874 \mathrm{~cm}^{-1}$ and $2852 \mathrm{~cm}^{-1}$ was found to decrease by $42.29 \%$ in cultured fish liver cells $(p=0.05)$. The frequency of the

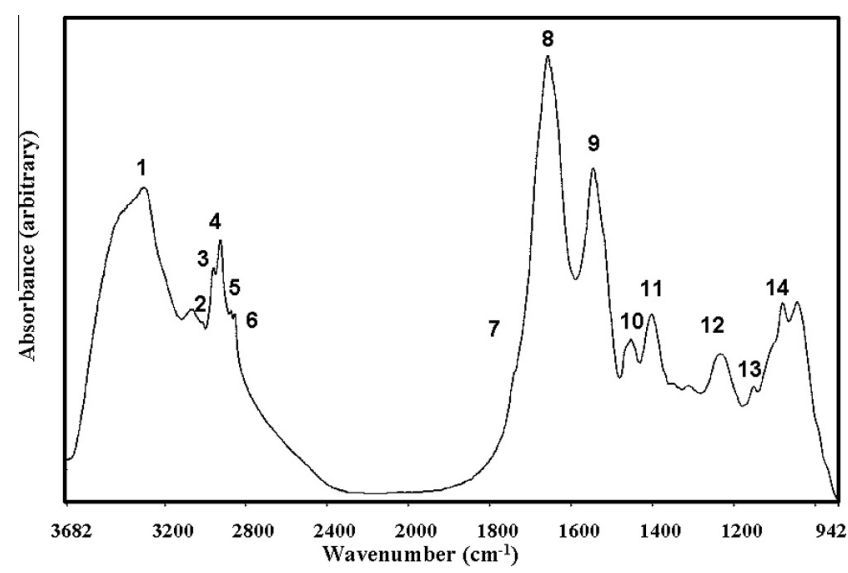

Fig. 1. The general FT-IR spectrum of Sparus aurata liver cells in $3700-940 \mathrm{~cm}^{-1}$ region. 
Table 1

The general FTIR band assignments of Sparus aurata liver cells.

\begin{tabular}{|c|c|c|}
\hline $\begin{array}{l}\text { Band } \\
\text { number }\end{array}$ & $\begin{array}{l}\text { Wave numbers } \\
(\mathrm{cm})\end{array}$ & Definition of the spectral assignment \\
\hline 1 & 3300 & $\begin{array}{l}\text { Amide A: Mainly } \mathrm{N}-\mathrm{H} \text { stretching of proteins with the little contribution from } \mathrm{O}-\mathrm{H} \text { stretching of polysaccharides and } \\
\text { intermolecular bonding }\end{array}$ \\
\hline 2 & 3012 & Olefinic $=\mathrm{CH}$ stretching vibration unsaturated lipids, cholesteryl esters \\
\hline 3 & 2959 & $\mathrm{CH}$ asymmetric stretching: lipids, protein side chains, with some contribution from carbohydrates and nucleic acids \\
\hline 4 & 2925 & CH asymmetric stretching: mainly lipids and the little contribution from proteins, carbohydrates and nucleic acids \\
\hline 5 & 2873 & $\mathrm{CH}$ asymmetric stretching: protein side chains, lipids, with some contribution from carbohydrates and nucleic acids \\
\hline 6 & 2854 & CH asymmetric stretching: mainly lipids, with the little contribution from proteins, nucleic acids and carbohydrates \\
\hline 7 & 1746 & Ester $\mathrm{C}=\mathrm{O}$ stretching: triglycerides and cholestrol esters \\
\hline 8 & 1657 & Amide I: proteins, mainly $\mathrm{C}=\mathrm{O}$ stretch \\
\hline 9 & 1545 & Amide I: proteins, mainly $\mathrm{N}-\mathrm{H}$ bend and $\mathrm{C}-\mathrm{N}$ stretch \\
\hline 10 & 1453 & $\mathrm{CH}$ bending: mainly lipids, with the little contribution from proteins, $\mathrm{CH}$ asymmetric bending: methyl group of proteins \\
\hline 11 & 1401 & $\begin{array}{l}\text { COO symmetric stretching: mainly lipids with the little contribution from proteins; } \mathrm{CH} \text { symmetric bending: methyl group of } \\
\text { proteins }\end{array}$ \\
\hline 12 & 1227 & PO symmetric stretching, fully hydrogen bonded: mainly nucleic acids with the with the little contribution from phospholipids \\
\hline 13 & 1151 & C-O stretching glycogen \\
\hline 14 & 1079 & PO symmetric stretching: nucleic acids and phospholipids; $\mathrm{C}-\mathrm{O}$ stretch glycogen \\
\hline
\end{tabular}
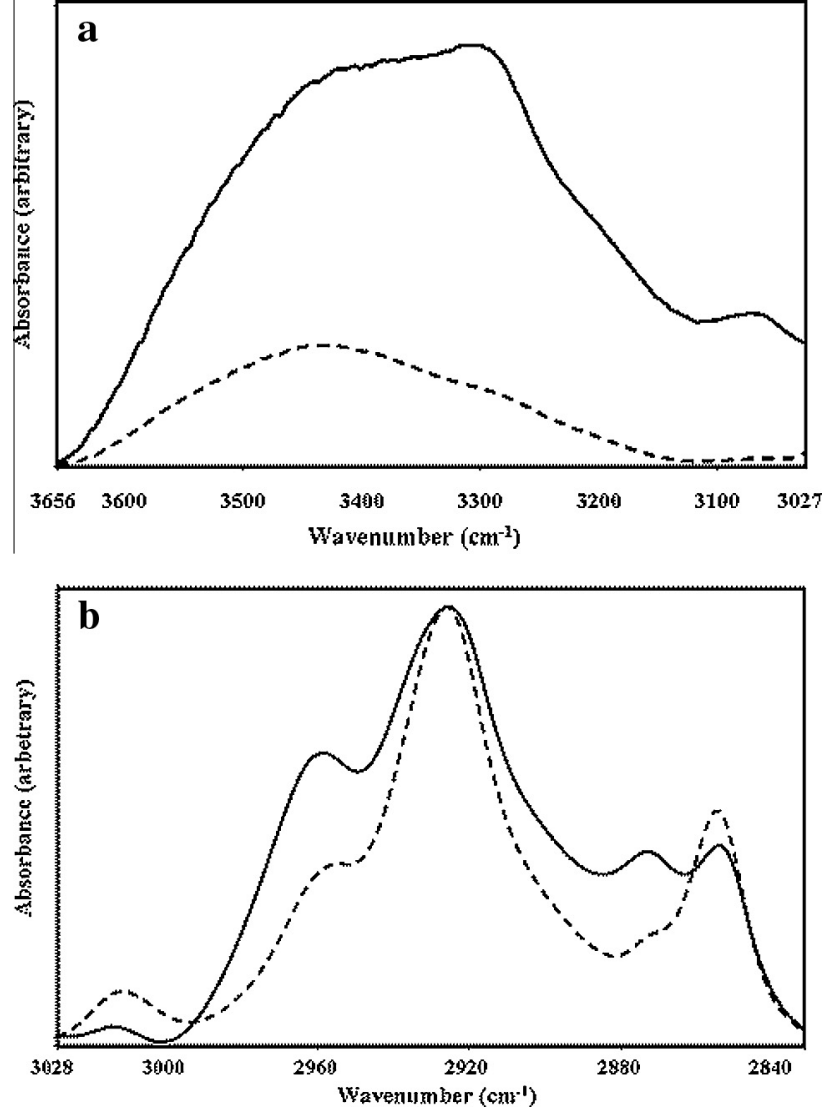

Fig. 2. The FT-IR spectra of wild fish (solid line) and cultured fish (dotted line) liver cells in the (a) $3660-3028 \mathrm{~cm}^{-1}$ and (b) $3028-2840 \mathrm{~cm}^{-1}$ regions (the spectra were normalised with respect to $\mathrm{CH}_{2}$ asymmetric mode, which is observed at $2925 \mathrm{~cm}^{-1}$ ).

$\mathrm{CH}_{2}$ asymmetric stretch band around $2926 \mathrm{~cm}^{-1}$ band shifted from $2926.53 \pm 0.7419$ to $2925.96 \pm 0.204 \mathrm{~cm}^{-1}$ in cultured fish liver cells.

The changes in the intensity of the band at $3011 \mathrm{~cm}^{-1}$ reflects the level of unsaturation in the acyl chains (Takahashi, French, \& Wong, 1991). As seen in Fig. 2b the intensity of the band at $3011 \mathrm{~cm}^{-1}$ increases for the cultured fish liver cells. For the wild fish liver cells the unsaturation level of lipids based on the $\mathrm{CH}=\mathrm{CH} / \mathrm{CH}_{2}$ ratio was found to be $0.0672 \pm 0.0256$ and for the cultured fish liver cells the ratio was $0.1599 \pm 0.0083(p=0.05)$.

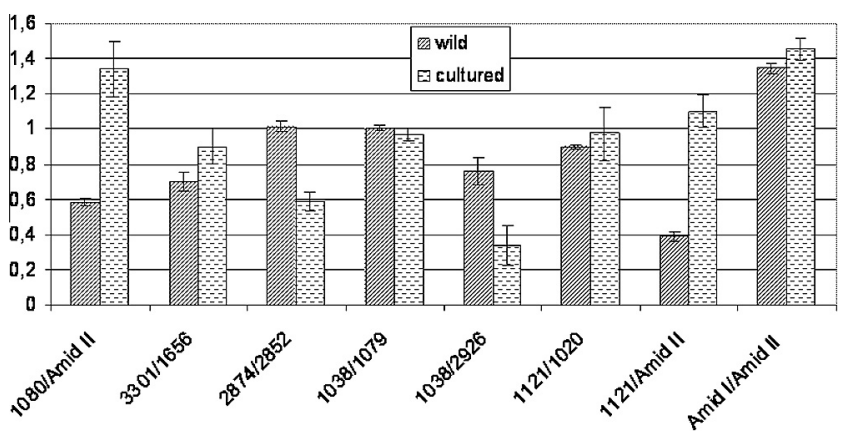

Fig. 3. The intensity-ratio values of the bands for the wild and cultured Sparus aurata liver cells. The values are the mean \pm standard deviation for each group.

In Fig. 2b $\mathrm{CH}_{3}$ asymmetric stretching vibration absorption intensity was observed to decrease in the cultured fish liver tissue indicating a change in the composition of the acyl chains in lipids (Takahashi et al., 1991). In addition to the changes in the $\mathrm{CH}_{3}$ asymmetric stretching mode, the intensity of the $\mathrm{CH}_{2}$ symmetric stretching band increased in the cultured fish tissue indicating an increasing proportion of the $\mathrm{CH}_{2}$ groups in the cultured fish tissue.

The $\mathrm{CH}_{2}$ asymmetric stretching band shifting was also analysed and was found to decrease (2926.53 \pm 0.74 (for wild fish liver cells) and $2925.96 \pm 0.20$ (for cultured fish liver cells)) indicating an increase in the cell membrane order as mentioned in Elibol-Can et al. (2011).

As seen in Fig. 2b, the intensity of the band at $3012 \mathrm{~cm}^{-1}$ indicates that the population of unsaturated lipids increased in the cultured fish liver tissue. The increase in the intensity of this band indicates a change in phospholipid metabolism with an increase in the unsaturated lipids (Takahashi et al., 1991). In addition the increase in the olefinic band may be due to the accumulation of end products of lipid peroxidation (Severcan, Gorgulu, Gorgulu, \& Guray, 2005). The unsaturation level for the cultured fish liver tissue was observed to be more than that of the wild fish liver cells. Lipoid liver disease, a significant problem in farmed fish, is usually linked to rancidity (auto-oxidation) of fats in fish feeds (Saraiva, Eiras, \& Bucke, 1986). Clinical and pathological correlates include reduced haematocrit, an abundance of ceroid-laden macrophages in visceral organs, and an enlarged pale, friable liver due to macrovesicular lipidosis (Winston, 1991).

A precise protein-to-lipid ratio can be derived by calculating the area ratio of the $\mathrm{CH}_{3}$ symmetric stretching $\left(2874 \mathrm{~cm}^{-1}\right)$ to the $\mathrm{CH}_{2}$ symmetric stretching vibration $\left(2852 \mathrm{~cm}^{-1}\right)$ from the FT-IR spectra. The intensity ratio of $2874 \mathrm{~cm}^{-1}$ and $2852 \mathrm{~cm}^{-1}$ was found 
to decrease by $42.29 \%$ in the cultured fish liver tissue. These results indicate a drastic increase in the lipid content of the cellular material for constant protein content. This conclusion is supported by the results obtained from the bands around $1743 \mathrm{~cm}^{-1}$. The change in the intensity of the band around $1743 \mathrm{~cm}^{-1}$ indicated the changes in the ratio of triglycerides and cholesterol esters and their saturation states. As opposed to wild fish in their niches cultured fish are restricted in their movement ability to a restricted area. Since wild fish needs to move around for feeding reasons they use their lipids in the need for energy. This energy requirement is carried out at least in part by the liver tissue. Thus the extra nutrients are stored in the liver of cultured cells as lipids increasing lipid/protein ratio. Fish nutrition is a matter of great importance in the expanding Mediterranean aquaculture industry as better product quality and optimum growth can be achieved using the appropriate diets. The most important species for fish farming in the region are the carnivorous species gilthead sea bream ( $S$. aurata) and European sea bass (Dicentrarchus labrax). S. aurata is known to require high levels of protein in its diet (Hidalgo \& Alliot, 1988; Perez, Gonzalez, Jover, \& Fernandez-Carmona, 1997). Fats are usually used to offer the necessary energy in order to cover the metabolic needs instead of proteins. Fats also supply highly unsaturated fatty acids of the $n-3$ series, which are considered indispensable for marine species (Sargent, Bell, Bell, Henderson, \& Tocher, 1995). The combined effect of dietary lipid level and fish meal quality is of crucial importance to obtain optimal growth and reduce final production costs. However, the effect of both mentioned parameters on the quality of the produced fish must be also considered.

The liver of fish plays an important role in intermediary metabolism storage of reserve compounds such as lipids (triacyglycerol) and glycogen. Metabolism of the energy rich storage products is variable, especially depending on water temperature, reproductive and nutritional status as well as age and state of health of the fish (Yıldız, Şener, \& Timur, 2007). Due to nutrition of cultured fish with high-lipid feed an accumulation of both lipids and carbohydrates is observed in fish hepatocytes.

Hepatosomatik indices of cultured fish were significantly higher than those of wild fish. The main components of liver tissue were irregular cords of hepatocytes arranged in tubules which surrounded vascular sinusoids. The hepatocytes contained an abundance of lipid much of which appeared to be neutral lipids of the cultured fish. Total and neutral lipid droplets were larger and the area occupied by these droplets was significantly greater in both cultured females and males compared to the wild fish, suggesting lipidosis in the cultured fish (Fahraeus-Van Ree \& Spurrell, 2003).

Fig. 4a shows the average FTIR spectra of the wild and cultured fish liver cells in the $1770-1470 \mathrm{~cm}^{-1}$ spectral region. As seen in Fig. $4 \mathrm{a}$, the intensity and frequency of the $\mathrm{C}=\mathrm{O}$ ester stretching vibration increased significantly in the cultured fish liver cells. The bands at $1657 \mathrm{~cm}^{-1}$ and $1545 \mathrm{~cm}^{-1}$ are amide I and amide II bands of proteins. Amide I and amide II bands are known to be sensitive to protein conformation (Cakmak et al., 2006) and are used to determine the secondary structure content of proteins. Changes in the shapes of these two bands indicated changes in the proteomes of the cultured fish liver cells. In Fig. 3 the ratio of the intensities of Amide I/Amide II bands increased (8.03\%) for the cultured fish liver cells $(p=0.05)$. The structural changes in proteins are seen from the intensities of the sub-bands in Amide I secondary derivative spectra as seen in Fig. $4 \mathrm{~b}$.

There were changes in the shapes of the Amide I and II bands as seen in Fig. 4a. Since Amide I band frequency and shape is sensitive to protein conformation, this shifting and shape changes are attributed to the changes in protein conformation (Jackson et al., 1999).The intensity ratio of Amide I/Amide II is another measure of protein conformational changes. This ratio was found to increase
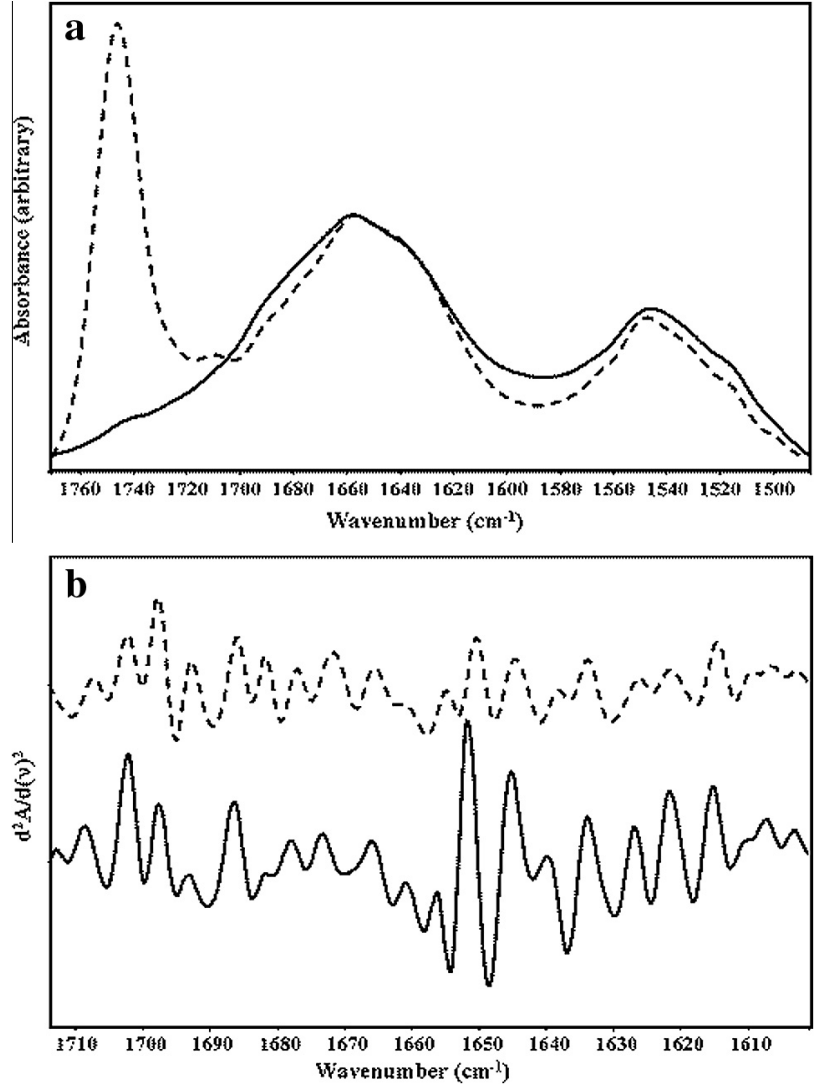

Fig. 4. The average (a) FT-IR spectra (the spectra were normalised with respect to Amid I band which is observed at $1657 \mathrm{~cm}^{-1}$ ) and (b) the second derivative spectra of the wild (solid line) and cultured fish (dotted line) liver cells in the 1770 $1470 \mathrm{~cm}^{-1}$ region.

7.43\% for the cultured fish tissue indicating protein secondary structural changes. In this study this change describes a total change in the proteome and protein structural changes of that proteome (Zhou, Wang, Sun, Liu, \& Zhang, 2001).

Fig. $5 \mathrm{a}$ and $\mathrm{b}$ show the average FTIR spectra of the wild and cultured fish liver cells in the $940-1480 \mathrm{~cm}^{-1}$ spectral region. In the average spectra the cultured fish liver the band was observed to shift towards the higher wavenumbers $\left(1462 \mathrm{~cm}^{-1}\right)$ in Fig. $5 \mathrm{a}$. The band at $1401 \mathrm{~cm}^{-1}$ disappears in the cultured fish liver spectra; however, new bands arise at the wavenumbers of $1416 \mathrm{~cm}^{-1}$ and $1379 \mathrm{~cm}^{-1}$.

The band at $1232 \mathrm{~cm}^{-1}$ appeared to become less pronounced and showed a shift toward higher wavenumbers in the cultured fish liver cells. A new band at $1100 \mathrm{~cm}^{-1}$ appears in the cultured liver cells. A notable increase in the intensity at $1151 \mathrm{~cm}^{-1}$ band was observed in the cultured fish liver cells as seen in Fig. 5b. In addition, the frequency of the band around $1080 \mathrm{~cm}^{-1}$ band shifted from $1079.318 \pm 0.0942$ to $1081.2778 \pm 1.5139 \mathrm{~cm}^{-1}$ in cultured fish liver cells $(p=0.05)$.

The intensity ratio of the $1030 \mathrm{~cm}^{-1}$ and $1080 \mathrm{~cm}^{-1}$ bands decreased by $3.58 \%$ in the cultured fish liver cells $(p>0.05)$ as seen in Fig. 3. Similarly, in the same figure the intensity ratio of $1039 \mathrm{~cm}^{-1}$ and $2926 \mathrm{~cm}^{-1}$ bands decreased by $55.78 \%(p=0.05)$; $1080 \mathrm{~cm}^{-1}$ and Amide II bands increased by $56.39 \%(p<0.05)$ and $1121 \mathrm{~cm}^{-1}$ and Amide II bands increased by $64.84 \%(p=0.05)$ in cultured fish liver cells. However, a considerable increase $(7.92 \%)$ in the intensity ratio of the $1121 \mathrm{~cm}^{-1}$ and $1020 \mathrm{~cm}^{-1}$ bands was observed in the cultured fish liver cells $(p>0.05)$ as seen in Fig. 3. This band appears to be more pronounced and broadened in the cultured fish liver cells and band shifts down to $1039.43 \mathrm{~cm}^{-1}$ in the cultured fish liver cells $(p=0.05)$. 

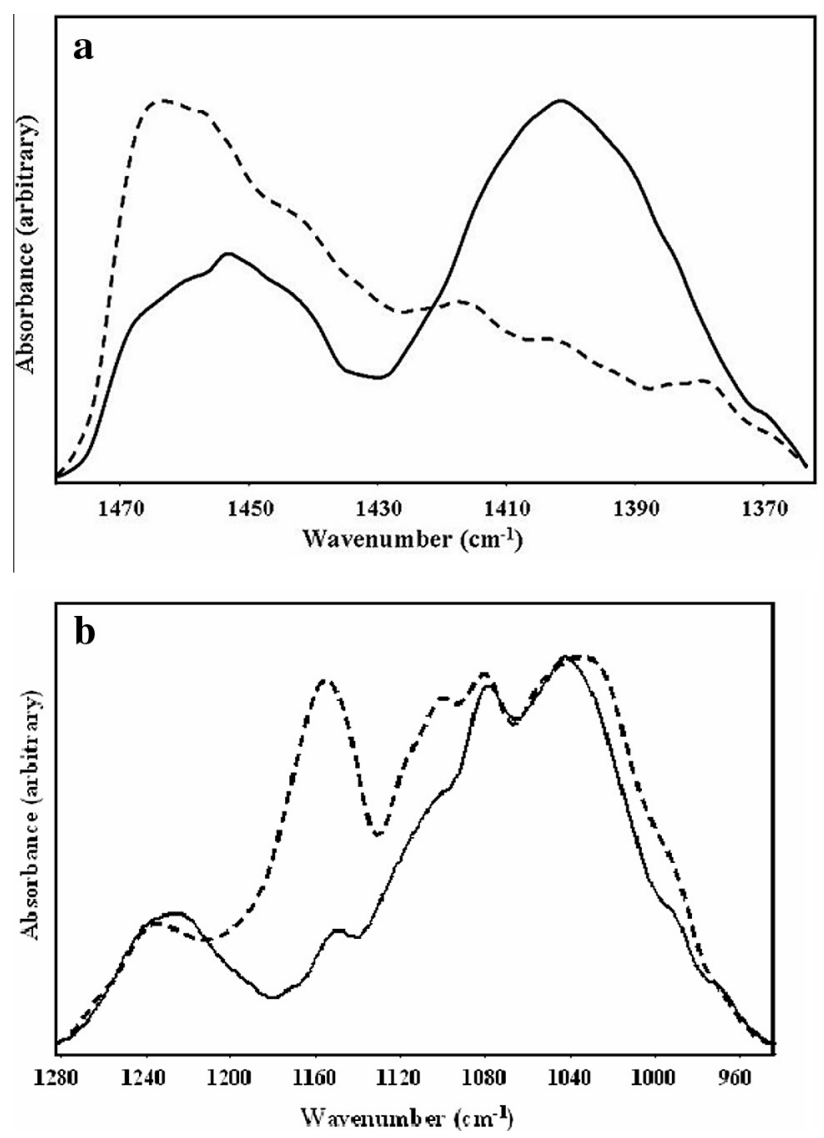

Fig. 5. The FT-IR spectra of the wild (solid line) and cultured (dotted line) fish liver cells in the (a) 1480-1363 $\mathrm{cm}^{-1}$ region (the spectra were normalised with respect to the band at $1401 \mathrm{~cm}^{-1}$ ) and in the (b) 1282 and $943 \mathrm{~cm}^{-1}$ (the spectra were normalised with respect to the band, at $1042 \mathrm{~cm}^{-1}$ ).

Glucose/phosphate ratio is a reliable measure for metabolic turnover of the cells (Ramesh et al., 2001) and it is indicated by the intensity ratio of the $1030 \mathrm{~cm}^{-1}$ and $1086 \mathrm{~cm}^{-1}$ bands. The glucose/phosphate ratio was found to decrease by $3.58 \%$ in the cultured fish liver tissue. The phosphate level was higher for normal cells carbohydrate levels also showed a corresponding increase than for H-ras transfected malignant cells (Ramesh et al., 2001). In a study by Gazi et al. the intensity ratio of the $1030 \mathrm{~cm}^{-1}$ and $1086 \mathrm{~cm}^{-1}$ bands was interpreted as glycogen-to-phosphate ratio and proposed as a marker for cancer to distinguish benign and malignant prostate cancer and they concluded that the ratio decreased in human malignant tissue (Gazi et al., 2003). Their findings indicate a close connection between carbohydrate and lipid metabolisms in the development of malignant cancer cells and the subject should be investigated metabolically. This study indicated a decrease in the metabolic turn over of cultured fish liver cells similar to H-ras induced human cancer formation.

The intensity ratio of $1038 \mathrm{~cm}^{-1}$ and $2926 \mathrm{~cm}^{-1}$ bands was found to decrease by $55.78 \%$ in the cultured fish tissue. This ratio is indicative of the ratio of glucose/phospholipids and is a measure of de novo synthesis of phospholipids at the expense of free glucose in the cell (Ramesh et al., 2001). This ratio was found to be larger for normal cells as compared to those transformed by H-ras (malignant cells) (Carnero et al., 1994).

The intensity of the $1086 \mathrm{~cm}^{-1}$ band is due to symmetric phosphate stretching of nucleic acids and its ratio to the Amide II band at $1545 \mathrm{~cm}^{-1}$ is used to estimate DNA/protein ratio in the cellular systems investigated (Mourant, Yamada, Carpenter, Dominique, \& Freyer, 2003b). In this study the intensity ratio of $1080 \mathrm{~cm}^{-1}$ and
Amide II bands increased by $56.39 \%$ in the cultured fish tissue indicating a small increase in the DNA over protein amount. Similar increases in this ratio were observed in differentiated and apoptotic cells (Zhou et al., 2001).

A significant increase $(7.92 \%)$ in the intensity ratio of the $1121 \mathrm{~cm}^{-1}$ band and $1020 \mathrm{~cm}^{-1}$ band was observed in the cultured fish tissue. This ratio is often used as an index of cellular RNA/DNA ratio. It is also interesting to note that there was a negative correlation between the RNA/DNA and glucose/phosphate ratios. This is considered to be a good indicator to identify the transforming status of the cells and is found to increase from normal to malignant cells (Ramesh et al., 2001).

The intensity ratio of the $1121 \mathrm{~cm}^{-1}$ and amide II bands increased by $64.84 \%$ in the cultured fish tissue. This ratio gives an idea about the transcriptional status of the cell. The results indicate that the transcriptional status of the cultured fish tissue cells increases.

The bands at $1239 \mathrm{~cm}^{-1}$ and $1086 \mathrm{~cm}^{-1}$ are nucleic acid bands. The $1239 \mathrm{~cm}^{-1}$ band is due to asymmetric phosphate stretching and the $1086 \mathrm{~cm}^{-1}$ band is due to symmetric phosphate stretching band of nucleic acids (Wong, Papavassiliou, \& Rigas, 1991). The frequencies of the both symmetric and asymmetric phosphate stretching bands were shifted to higher frequency values in the cultured fish tissue.

\section{Conclusion}

The results of the present study indicate that aquaculturing induces significant structural and physiological changes in the liver tissues of $S$. aurata tissue. The content of glycogen was found to increase in the cultured fish tissue. The amount of unsaturated lipids increased in the cultured fish liver tissue indicating lipid peroxidation. In addition, lipid membrane order was found to increase in the cultured fish liver tissue. The total proportion of cholesterol and triglycerides to protein increased significantly indicating steatosis. The structural/organisational changes in the nucleus were evident as revealed by frequency changes in the nucleic acid bands. Changes in the amide bands revealed changes in the proteome of the resistant cells. The transcriptional status of DNA was found to increase along with lower metabolic turn-over in the cultured fish liver tissue. The results of the present study also revealed that FTIR spectroscopy has the potential to be used as an analytical method of detecting and monitoring structural and functional changes in fish physiology. In addition FTIR spectroscopy provides an easy and a direct method to detect physiologic changes due to any histopathologic state without any histopathologic data or blood parameters. Similarly the method allows any researcher to distinguish between cultured and wild fishes.

\section{Acknowledgements}

We thank the staff of the Biotechnology and Bioengineering Center of Izmir Institute of Technology for their help and technical support. We also thank Department of Chemistry for allowing us to use the FTIR spectrometer.

\section{References}

Cakmak, G., Togan, I., \& Severcan, F. (2006). 17Beta-estradiol induced compositional, structural and functional changes in rainbow trout liver, revealed by FT-IR spectroscopy: A comparative study with nonylphenol. Aquatic Toxicology, 77, 53-63.

Çakmak, G., Togan, I., Uğuz, C., \& Severcan, F. (2003). FT-IR spectroscopic analysis of rainbow trout liver exposed to nonylphenol. Applied Spectroscopy, 57, 835-841.

Cakmak, G., Zorlu, F., Severcan, M., \& Severcan, F. (2011). Screening of protective effect of amifostine on radiation-induced structural and functional variations in rat liver microsomal membranes by FT-IR spectroscopy. Analytical Chemistry, 83, 2438-2444. 
Carnero, A., Cuadrado, A., Dolfi, F., Jimenez, B., Delpeso, L., Esteve, P., et al. (1994). Regulation of phospholipid-metabolism by ras proteins. Gtpase-Controlled Molecular Machines, 6, 321-340.

Ceylan, C., Severcan, F., Ozkul, A., Severcan, M., Bozoglu, F., \& Taheri, N. (2012). Biophysical and microbiological study of high hydrostatic pressure inactivation of Bovine Viral Diarrheavirus type 1 on serum. Veterinary Microbiology, 154, 266-271.

Chan, S. I., Bocian, D. F., \& Petersen, N. O. (1981). Nuclear magnetic resonance studies of the phospholipid bilayer membrane in membrane spectroscopy. Heidelberg: Springer Verlag.

Elibol-Can et al. (2011). The effects of short-term chronic ethanol intoxication and ethanol withdrawal on the molecular composition of the rat hippocampus by FT-IR spectroscopy. Alcoholism, Clinical and Experimental Research, 35(11), 1-13.

Fahraeus-Van Ree, G. E., \& Spurrell, D. R. (2003). Structure of and energy reserves in the liver of wild and cultured yellowtail flounder, Limanda ferruginea. Marine Biology, 143, 257-265.

Gazi, E., Dwyer, J., Gardner, P., Ghanbari-Siahkali, A., Wade, A. P., Miyan, J., et al. (2003). Applications of Fourier transform infrared microspectroscopy in studies of benign prostate and prostate cancer. A pilot study. The Journal of Pathology, 201, 99-108.

Hardy, R. W. (1989). Diet preparation. In J. E. Halver (Ed.), Fish nutrition (pp. 476-549). San Diego: Academic Press.

Hidalgo, F., \& Alliot, E. (1988). Influence of water temperature on protein requirement and protein utilization in juvenile sea bass, Dicentrarchus labrax. Aquaculture, 72, 115-129.

Jackson, M., Mansfield, J. R., Dolenko, B., Somorjai, R. L., Mantsch, H. H., \& Watson, P. H. (1999). Classification of breast tumors by grade and steroid receptor status using pattern recognition analysis of infrared spectra. Cancer Detection and Prevention, 23, 245-253.

Mourant, J. R., Gibson, R. R., Johnson, T. M., Carpenter, S., Short, K. W., Yamada, Y. R., et al. (2003a). Methods for measuring the infrared spectra of biological cells. Physics in Medicine E' Biology, 48, 243-257.

Mourant, J. R., Yamada, Y. R., Carpenter, S., Dominique, L. R., \& Freyer, J. P. (2003b). FTIR spectroscopy demonstrates biochemical differences in mammalian cell cultures at different growth stages. Biophysical Journal, 85, 1938-1947.

Perez, L., Gonzalez, H., Jover, M., \& Fernandez-Carmona, J. (1997). Growth of European sea bass fingerlings (Dicentrarchus labrax) fed extruded diets containing varying levels of protein, lipid and carbohydrate. Aquaculture, 156, 183-193.
Ramesh, J., Salman, A., Hammody, Z., Cohen, B., Gopas, J., Grossman, N., et al. (2001) Application of FTIR microscopy for the characterization of malignancy: H-ras transfected murine fibroblasts as an example. Journal of Biochemical and Biophysical Methods, 50, 33-42.

Roberts, R. J., \& Bullock, A. M. (1989). Nutritional pathology. In J. E. Halver (Ed.), Fish nutrition (pp. 423-475). San Diego: Academic Press.

Saraiva, A., Eiras, J. C., Bucke D., (1986). Lipoid liver degeneration and pseudobranch pathology in rainbow trout. In R. Salmo gairdneri (Ed.), İn Portugal. Bull. of the European Association of Fish Pathol., 6, (pp. 115-118).

Sargent, J. R., Bell, J. G., Bell, M. V., Henderson, R. J., \& Tocher, D. R. (1995) Requirement criteria for essential fatty acids. Journal of Applied Ichthyology, 11 $183-198$.

Segner, H., \& Juario, J. V. (1986). Histological observations on the rearing of milkfish, Chanos chanos, fry using different diets. Journal of Applied Ichthyology, 4 162-173.

Severcan, F., Gorgulu, G., Gorgulu, S. T., \& Guray, T. (2005). Rapid monitoring of diabetes-induced lipid peroxidation by Fourier transform infrared spectroscopy: Evidence from rat liver microsomal membranes. Analytical Biochemistry, 339, 36-40.

Takahashi, H., French, S. W., \& Wong, P. T. (1991). Alterations in hepatic lipids and proteins by chronic ethanol intake: A high-pressure Fourier transform infrared spectroscopic study on alcoholic liver disease in the rat. Alcoholism, Clinical and Experimental Research, 15, 219-223.

Winston, G. W. (1991). Oxidant and antioxidants in aquatic animals. Comparative Biochemistry and Physiology, 100C, 173-176.

Wong, P. T. T., Papavassiliou, E. D., \& Rigas, B. (1991). Phosphodiester stretching bands in the infrared-spectra of human tissues and cultured-cells. Applied Spectroscopy, 45, 1563-1567.

Yıldız, M., Sener, E., \& Timur, M. (2007). Effects of variation in feed and seasonal changes on body proximate composition of wild and cultured sea bass (Dicentrarshus labrax L.). Turkish Journal of Fisheries and Aquatic Sciences, 7, 45-52.

Zhou, J., Wang, Z., Sun, S., Liu, M., \& Zhang, H. (2001). A rapid method for detecting conformational changes during differentiation and apoptosis of HL60 cells by Fourier-transform infrared spectroscopy. Biotechnology and Applied Biochemistry, 33, 127-132. 